\author{
Ye.S. Panova ${ }^{1}$, Ye.A. Issabayev ${ }^{1}$, M.T. Baigaziyev ${ }^{1}$, \\ G.I. Boiko ${ }^{1}$, N.P. Lyubchenko ${ }^{1}$, R.G. Sarmurzina ${ }^{2}$

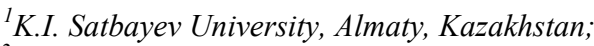 \\ ${ }^{2}$ «KazEnergy» Association, Astana, Kazakhstan \\ (E-mail:amtek@bk.ru)
}

\title{
Analysis of oil sludge and selection of solvents for the extraction method of petroleum products recovery
}

\begin{abstract}
Analysis of oil sludge formed in a storage tank for straight-run fuel oil of «Pavlodar Oil Chemistry Refinery» LLP was carried out in this work. Content of water, oil products and mechanical impurities was $12.4 \%$, $17.6 \%$ and $70 \%$, respectively. A sample of oil separated from the sludge was analyzed for the content of silica gel resins, paraffins and asphaltenes, and their group composition was studied using the IR spectrometry method. It was revealed that the oil sludge stabilizers belonged to the paraffin type. TG/DSC analysis was used to obtain information on the initial and final temperature of the thermal decomposition of the oil sludge. It was shown that oil products are completely burned to a temperature of $600{ }^{\circ} \mathrm{C}$. This temperature was used for calcining oil sludge. The phase composition of mechanical impurities isolated from the oil sludge was determined by X-ray diffraction analysis. According to the data obtained from X-ray diffraction analysis, main constituents of the mineral part of the oil sludge were quartz sand $(63.1 \%)$ and albite $(16.5 \%)$. The most optimal mixture of solvents (white spirit: hexane) for extracting petroleum products from the oil sludge was obtained using the extraction method.
\end{abstract}

Keywords: oil sludge, mechanical impurities, solvent, extraction, paraffins, resins, asphaltenes, TG/DSC analysis.

\section{Introduction}

Oil sludge is a complex physico-chemical mixture consisting of water, oil products and mechanical impurities (clay, sand, metal oxides). These components are well mixed and stabilized. The oil phase primarily consists of saturated and aromatic hydrocarbons, asphaltenes and resins [1-4]. A significant amount of oil sludge is produced by the oil industry during production, transportation, storage and refinery. In oil refineries, sludge is formed during processes of fluid catalytic cracking, visbreaking, air flotation and wastewater treatment. Oil sludge accumulates in sedimentation tanks and at the bottom of storage tanks, occupying a working volume $[3,5-7]$. Storage of oil sludge causes complex environmental problems, while the oil part of it is a valuable organic raw material. As a result of utilization it is possible to obtain such commodity products as hydrocarbon gas, commercial fuel components, lubricants, bitumen etc., as well as recycling products such as uncultivated soil, ash, soot, gaseous components.

Several methods of processing oil sludges are known with the aim of reducing toxicity, minimizing the volume of oil sludge and extracting petroleum products. Flotation, pyrolysis, combustion, biodegradation, freezing/thawing, ultrasonic treatment, electrical processing, microwave radiation and solvent extraction are among them [3,4]. Their effectiveness depends on the properties of specific oil sludge such as macrostructure and chemical composition [8]. However, most of the methods are expensive, requiring a long time and even causing secondary pollution of the environment [6]. Based on the analysis of literature data extraction of sludge by a solvent is the most effective method of extracting petroleum among the listed methods, which is characterized by low energy costs [7]. In connection with the foregoing the authors of this paper had aim to analyze the oil sludge and offer the most effective solvent or solvent system for recovering petroleum products by the extraction method based on the data obtained. A sample of oil sludge taken from the storage tank of straight-run heavy fuel oil of «Pavlodar Oil Chemistry Refinery» LLP was selected as a research object of this work.

\section{Experimental}

The composition of the sludge was determined by the gravimetric method. A sample of oil sludge $(10 \mathrm{~g})$ was dried to constant mass in a thermal oven at $105^{\circ} \mathrm{C}$. The weight loss of the sample was corresponded to the water content of the sludge. The water content determined by the described method corresponds to the water content obtained by the Dean-Stark Method (State standard 2477-65). The content of 
petroleum products in the sludge was calculated from the weight loss of the sludge sample subjected to heat treatment in a muffle furnace at $600^{\circ} \mathrm{C}$. A sample of oil extracted from the sludge was analyzed for the content of silica gels (State standard 11858-66), paraffins (State standard 11851-85), resins and asphaltenes (State standard 11858-66*).

\section{Results and discussion}

It was noted that oil from the sludge is characterized by a relatively large content of silica gel resins (R) and paraffins (P) $4.67 \mathrm{wt} . \%$ and $6.88 \mathrm{wt}$. \% respectively. The content of asphaltenes (A) $1.98 \mathrm{wt} \%$. It is known that, depending on the ratio $(\mathrm{R}+\mathrm{A}) / \mathrm{P}$, oil sludge stabilizers can be subdivided into the following types, namely, asphaltene ( $(\mathrm{R}+\mathrm{A}) / \mathrm{P} \geq 1.0)$; paraffin $((\mathrm{R}+\mathrm{A}) / \mathrm{P} \leq 1.0)$; mixed $((\mathrm{R}+\mathrm{A}) / \mathrm{P} \approx 1.0)$. The stabilizers of the sludge investigated were assigned to the paraffin type based on the data obtained.

The group composition of isolated paraffins, resins and asphaltenes were studied by IR spectroscopy at $20{ }^{\circ} \mathrm{C}$ on a Cary 660 FT-IR spectrometer (Fig. 1). From the IR spectrum of paraffin (Fig. 1a) it can be seen that its composition contains an intense set of absorption bands in the 2920 and $2852 \mathrm{~cm}^{-1}$ region that corresponds to stretching vibrations of $\mathrm{C}-\mathrm{H}$ bonds of methyl and methylene groups. The absorption bands in the $1464 \mathrm{~cm}^{-1}$ region are due to bending vibrations of $-\mathrm{CH}_{2}$ and $-\mathrm{CH}_{3}$ groups. The absorption band in the region of $1271 \mathrm{~cm}^{-1}$ indicates the presence of unbranched paraffin chains [9]. It follows from Figure 1 that the resin is characterized by a high content of $\mathrm{C}-\mathrm{H}$ bonds of saturated hydrocarbons in the regions of the absorption bands 1377, 1459, 2861, $2922 \mathrm{~cm}^{-1}$. The absorption bands in the IR spectra of 1018 and $1704 \mathrm{~cm}^{-1}$ indicate the presence in the samples of both aromatic structures and carbonyl groups. Asymmetric and symmetrical oscillations of $-\mathrm{CH}_{3}$ and $-\mathrm{CH}_{2}$ groups at $2926,2857 \mathrm{~cm}^{-1}$ are observed in the spectrum of asphaltenes (Fig. 1c). The absorption bands around $1700 \mathrm{~cm}^{-1}$ are due to the presence of carbonyl groups.

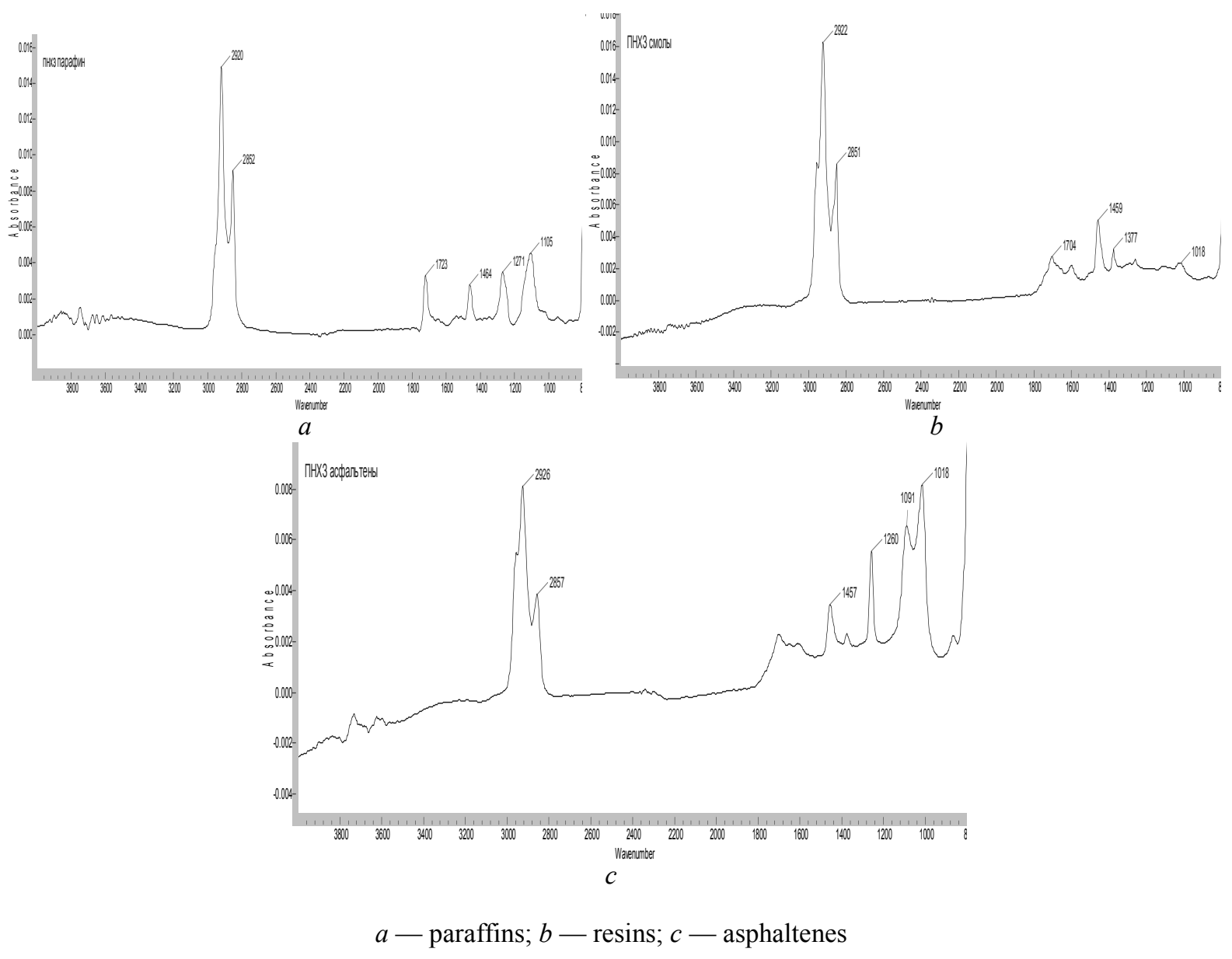

Figure 1. FT-IR spectra of components of oil sludge

Figure 2 presents photographs of samples of oil sludge before and after calcination. Figure $2 a$ shows that oil sludge is a mass of black color. The sample acquired a ginger color and became crumbly after calci- 
nation at $600{ }^{\circ} \mathrm{C}$ (Fig. $2 b$ ). Thus, it can be concluded that all petroleum products are oxidized and burned during calcination at temperature of $600^{\circ} \mathrm{C}$.

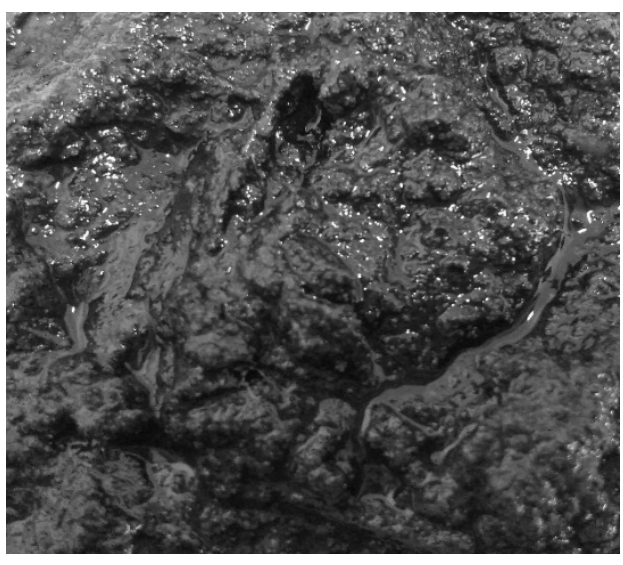

$a$

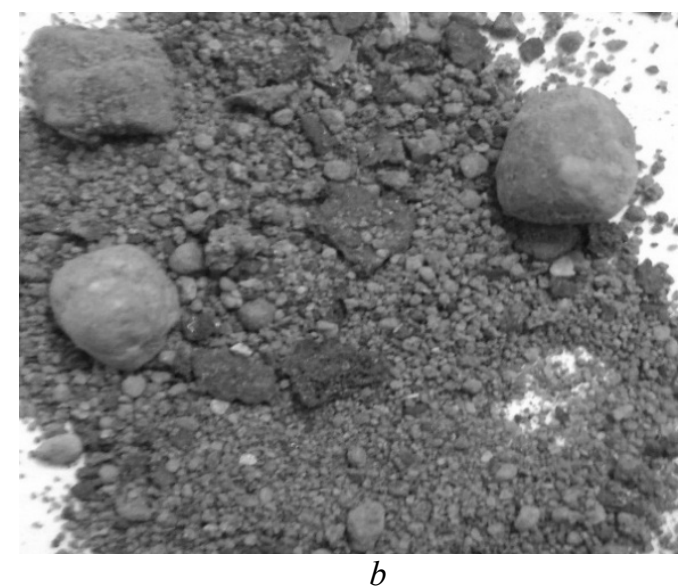

b

$a$ - a sample of the original oil sludge; $b$ - a sample of oil sludge after calcination at $600{ }^{\circ} \mathrm{C}$

Figure 2. Photographs of oil sludge before and after calcination

Oil sludge investigated was analyzed on TG/DSC to obtain information on the initial and final temperature of thermal decomposition. The studies were performed on a differential scanning calorimeter DSC 131 evo from Setaram at a temperature range from $25^{\circ} \mathrm{C}$ to $900{ }^{\circ} \mathrm{C}$. The scanning was performed at a velocity of $20^{\circ} \mathrm{C} / \mathrm{min}$. The results of the analysis are shown in Figure 3.

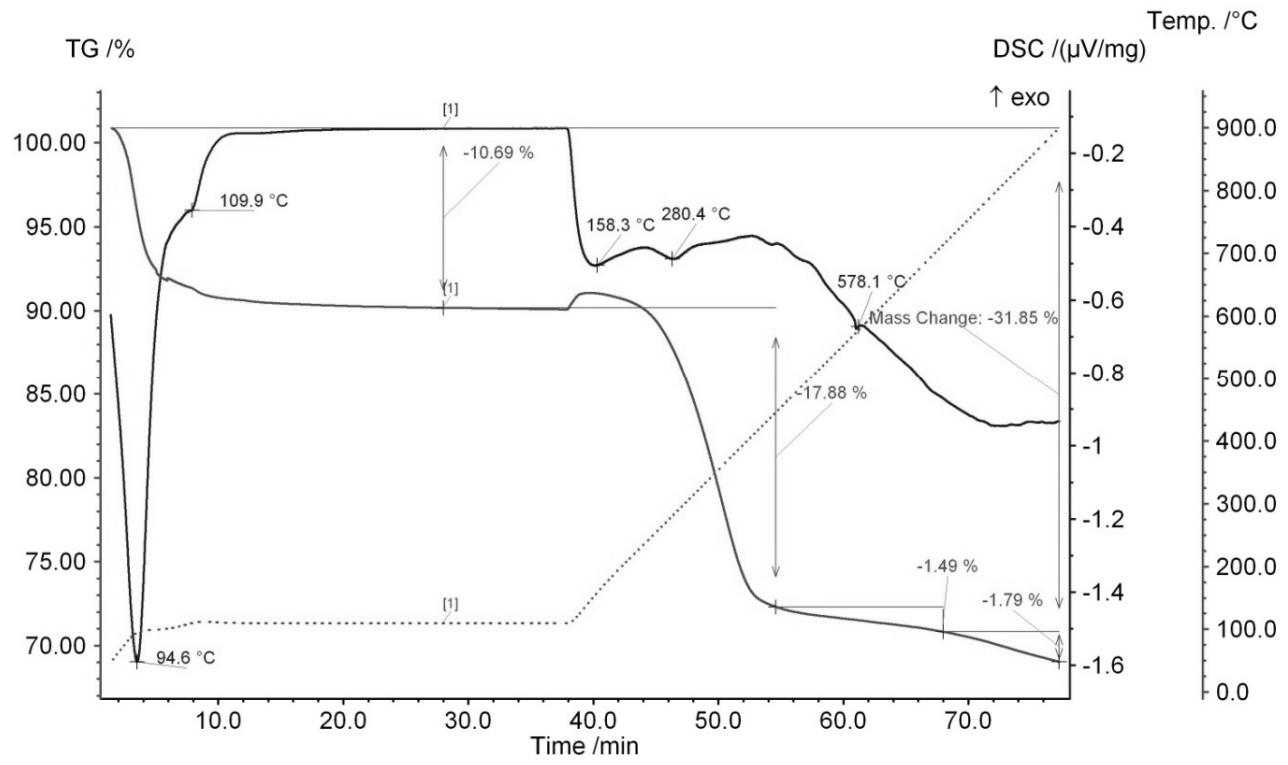

Figure 3. Thermogram of the oil sludge

Several stages of mass loss can be observed from the curves of TG and DSC of oil sludge shown in Figure 3 at temperatures below $160^{\circ} \mathrm{C}$, the mass loss on the TG curves corresponds to the evaporation of moisture and light components whose boiling points are below $160^{\circ} \mathrm{C}[6]$. The thermogram shows the boiling range of the aqueous phase at a temperature of $94.6^{\circ} \mathrm{C}$. The mass loss during the evaporation of lightboiling components was $10.69 \%$. The largest loss of mass $(17.88 \%)$ is observed at temperatures from $158.3^{\circ} \mathrm{C}$ to $578{ }^{\circ} \mathrm{C}$. The exothermic peak $\left(280-578{ }^{\circ} \mathrm{C}\right)$ with a maximum at $450{ }^{\circ} \mathrm{C}$, according to the literature [9], refers to the oxidative cracking of hydrocarbons. The loss of mass observed above $600{ }^{\circ} \mathrm{C}$ is determined by the thermal decomposition of some inorganic mineral substances [10]. Using this method of research, it was shown that oil products are completely burned to a temperature of $600{ }^{\circ} \mathrm{C}$. Thus, the calcination temperature was found to determine the content of petroleum products in the oil sludge. 
Determination of the phase composition of mechanical impurities isolated from oil sludge calcined at $600{ }^{\circ} \mathrm{C}$ for 1 hour of oil sludge was carried out by X-ray diffraction analysis using a D8 Advance X-ray diffractometer (Bruker).

Ta b l e 1

Results of X-ray phase analysis of mechanical impurities of oil sludge

\begin{tabular}{|l|c|c|}
\hline \multicolumn{1}{|c|}{ Name } & Formula & Content, \% \\
\hline Silicon oxide & $\mathrm{SiO}_{2}$ & 63.1 \\
\hline Albite & $\mathrm{NaAl}\left(\mathrm{Si}_{3} \mathrm{O}_{8}\right)$ & 16.5 \\
\hline Orthoclase & $\mathrm{KAl}\left(\mathrm{Si}_{3} \mathrm{O}_{8}\right)$ & 6.9 \\
\hline Magnetite & $\mathrm{FeO} \cdot \mathrm{Fe}_{2} \mathrm{O}_{3}$ & 6.4 \\
\hline Muscovite & $\mathrm{KAl}_{2}\left(\mathrm{Si}_{3} \mathrm{AlO}_{10}\right)(\mathrm{OH})_{2}$ & 4.1 \\
\hline Kaolinite & $\mathrm{Al}_{2} \mathrm{O}_{3} 2\left(\mathrm{SiO}_{2}\right) 2 \mathrm{H}_{2} \mathrm{O}$ & 2.9 \\
\hline
\end{tabular}

According to the data obtained (Table 1), the main constituents of the mineral part of the oil sludge are quartz sand $(63.1 \%)$ and albite $(16.5 \%)$, silicates $(6.9 \%)$, magnetite $(6.4 \%)$, muscovite $(4.1 \%)$, kaolin $(2.9 \%)$. The mineral part of the oil sludge investigated, according to the results of the study, is suitable for use as components of building materials.

Thus, on the basis of a complex analysis of oil sludge, it was determined that the water content in the oil sludge under investigation was $12.4 \mathrm{wt} . \%$, the content of oil products was $17.6 \mathrm{wt} . \%$ and mechanical impurities was $70 \mathrm{wt} . \%$. As it is known from the literature [3] oil recovery is the most preferred option for the processing of oil sludge, it is noted that it is economically feasible to process sludge containing more than 10 mass\% of oil. Extraction-gravimetric method for oil sludge was used to select solvents that have an optimal ratio of dissolving power and the ability to break conglomerates of sparingly soluble components into small fragments.

$\mathrm{Tab} 1 \mathrm{e} 2$

\section{Results of experiments on the selection of solvents by extraction-gravimetric method} at the boiling point of solvents

\begin{tabular}{|l|c|c|}
\hline \multicolumn{1}{|c|}{$\begin{array}{c}\text { Solvent/mixture } \\
\text { of solvents }\end{array}$} & $\begin{array}{c}\text { Solvent ratio, } \\
\text { vol.\% }\end{array}$ & $\begin{array}{c}\text { Extraction rate } \\
\text { of oil products, \% }\end{array}$ \\
\hline Petroleum ether & 100 & 63.13 \\
\hline White Spirit & 100 & 71.02 \\
\hline Benzene & 100 & 74.60 \\
\hline Petrol & 100 & 82.95 \\
\hline Hexane & 100 & 89.60 \\
\hline Thinner 646 & 100 & 96.99 \\
\hline Gasoline: hexene & $95: 5$ & 88.30 \\
\hline Hexane : hexene & $95: 5$ & 92.05 \\
\hline White spirit : hexene & $95: 5$ & 97.44 \\
\hline
\end{tabular}

According to the results obtained (Table 2), the most effective solution for dissolving the sludge is a mixture of solvents such as white spirit with hexene, the degree of recovery of petroleum products with this mixture was $97.44 \%$ while in white spirit, which is a mixture of liquid aliphatic and aromatic hydrocarbons the recovery rate does not exceed $71 \%$. Good results were obtained using a solvent 646 , in which toluene, butyl acetate, acetone, butanol, ethyl alcohol are present. The recovery rate of oil products was $96.99 \%$. Petroleum ether was the least effective solvent as it is a mixture of light aliphatic hydrocarbons; the content of dissolved petroleum products in it was $63.13 \%$. It can be noted that an increase in the efficiency of solvents is observed when an unsaturated hydrocarbon (hexene) is added to them.

A series of experiments were carried out to select the optimal ratio of hydrocarbons in white spirit: hexene mixture in order to extract oil products from oil sludge efficiently. Mass ratio of oil sludge : solvent was held at 1:4 and the dissolution time was 1 hour. The maximum yield of petroleum products $17.15 \%$ by weight was observed at a volume ratio of white spirit : hexene 95:5. In this connection, for a given ratio of a mixture of hydrocarbons, studies were carried out on the selection of the oil sludge: solvent optimal ratio. 
The data indicate that for the oil sludge and solvent mixture of white spirit : hexene (95:5) the ratio $1: 4$ is optimal.

\title{
Conclusions
}

Thus, an analysis of oil sludge from a storage tank for straight-run fuel oil was carried out. According to the TG/DSC analysis, it was found that water evaporation occurred at $94.6^{\circ} \mathrm{C}$, mass loss in the $158.1-$ $578.3^{\circ} \mathrm{C}$ region corresponds to the combustion of organic substances, and at a higher temperature, some inorganic mineral compounds are expected to decompose. It is established that the mineral part of the oil sludge was mainly represented by quartz. The most optimal mixture of solvents for extracting petroleum products from oil sludge was extracted using the extraction method. The best results were obtained by using a mixture of white spirit : hexene in a weight ratio of 95:5, the ratio of oil sludge : solvent 1:4. At this ratio, the recovery of oil from the sludge was almost $98 \%$.

\section{References}

1 Ахметов А.Ф. Методы утилизации нефтешламов различного происхождения / А.Ф. Ахметов, А.Р. Гайсина, И.А. Мустафин // Нефтегазовое дело. — 2011. — Т. 9, № 3. - С. 98-101.

2 Wang J. Production and characterization of high quality activated carbon from oily sludge / J. Wang, T. Liu, Q. Huang, Z.Ma, Y. Chi, J. Yan // Fuel Processing Technology. — 2017. — No. 162. — P. 13-19.

3 Liang J. Solid effect in solvent extraction treatment of pre-treated oily sludge / J. Liang, L. Zhao, N. Du, H. Li, W. Hou // Separation and Purification Technology. - 2014. - No. 130. - P. 28-33.

4 Viana F.F. Aged oil sludge solubilization using new microemulsion systems: Design of experiments / F.F. Viana, T.N. Dantas, C.G. Rossi, A.A. Neto, M.S. Silva // Journal of Molecular Liquids. — 2015. — No. 210. — P. 44-50.

5 Elektorowicz M. Removal of Heavy Metals from Oil Sludge Using Ion Exchange Textiles / M. Elektorowicz, Z. Muslat // Environmental Technology. — 2008. — Vol. 29, No. 4. - P. 393-399.

$6 \mathrm{Hu}$ J. Extraction of crude oil from petrochemical sludge: Characterization of products using thermogravimetric analysis / J. Hu, J. Gan, J. Li, Y. Luo, G. Wang, L. Wu, Y. Gong // Fuel. — 2007. — No. 188. — P. 166-172.

7 Zubaidy E.A. Fuel recovery from waste oily sludge using solvent extraction / E.A. Zubaidy, D.M. Abouelnasr // Process Safety and Environmental Protection. - 2010. - Vol. 88, No. 5. - P. 318-326.

8 Ermakov V.V. Oil sludge depository assessment using multivariate data analysis / V.V. Ermakov, A. Bogomolov, D.E. Bykov // Journal of Environmental Management. - 2012. - No. 105. — P. 144-151.

9 Бойко Г.И. Оценка состава асфальтосмолопарафиновых отложений и нефти месторождения «Кумколь» методами термического и ИК-спектроскопического анализов / Г.И. Бойко, Г.С. Айткалиева, Е.М. Шайхутдинов, Н.П. Любченко, Т.П. Маймаков, Р.Г. Сармурзина, К.М. Касымгалиев, У.С. Карабалин // Нефтяное хозяйство. — 2015. — № 6. — С. 80-82.

10 Saikial N.J. Thermogravimetric combustion kinetics of petroleum effluent treatment plant sludge / N.J. Saikial, P. Sengupta, P.K. Gogoi, P.C. Borthakur // Journal of Thermal Analysis and Calorimetry. — 2005. - Vol. 79, No. 3. - P. 653-662.

11 Bai, F. Thermal and kinetic characteristics of pyrolysis and combustion of three oil shales / F. Bai, Y. Sun, Y. Liu, Q. Li, M. Guo // Energy Conversion and Management. — No. 97. - P. 374-381.

\author{
Е.С. Панова, Е.А. Исабаев, М.Т. Байгазиев, \\ Г.И. Бойко, Н.П. Любченко, Р.Г. Сармурзина
}

\section{Мұнай өнімдерін экстракциялық әдіспен бөліп алу үшін мұнай шламын талдау және еріткіштерді таңдау}

\begin{abstract}
Мақалада «Павлодар мұнай-химия зауыты» ЖШС мазутты сақтау резервуарынан алынған мұнай шламына талдау жүргізілді. Су, мұнай өнімдері мен механикалық қоспалардың мөлшері сәйкесінше $12,4 \%, 17,6 \%$ және 70 \% құрады. Шламнан бөлініп алынған мұнайдың сынамасы құрамында силикагель шайырлары, парафиндер және асфальтендер мөлшерін анықтау үшін талданды, сонымен қатар олардың топтық құрамы ИҚ спектрометриясы арқылы зерттелді. Мұнай-шламының тұрақтандырғыштары парафинді түріне жататындығы анықталды. Мұнай шламының термиялық ыдырауының бастапқы және соңғы температуралары жайлы ақпарат алу үшін ТГ/ДСК талдауы пайдаланылды. Мұнай өнімдері $600{ }^{\circ} \mathrm{C}$ температурада толығымен жанып кететіндігі байқалды. Сондықтан аталған температура мұнай шламын күйдіру үшін пайдаланылды. Мұнай шламынан бөлініп алынған механикалық қоспалардың фазалық құрамы D8 Advance (Bruker) рентген-фазалық дифрактометрі көмегімен рентген-фазалық талдау әдісімен анықталды. Алынған мәліметтер бойынша, кварц құмы $(63,1$ \%) және альбит (16,5 \%) мұнай шламының минералды бөлігінің негізгі құраушысы болып табылатындығы көрсетілді. Мұнай шламынан экстракция әдісімен мұнай өнімдерін бөліп алу
\end{abstract}


үшін еріткіштердің ең оңтайлы қоспасы таңдалды. Ең жақсы нәтиже уайт-спирит : гексен қоспасы арқылы алынды.

Кілт сөздер: мұнай шламы, механикалық қоспалар, еріткіш, экстракция, парафиндер, шайырлар, асфальтендер, ТГ/ДСК талдау.

\author{
Е.С. Панова, Е.А. Исабаев, М.Т. Байгазиев, \\ Г.И. Бойко, Н.П. Любченко, Р.Г. Сармурзина

\section{Анализ нефтяного шлама и подбор растворителей для экстракционного метода извлечения нефтепродуктов}

\begin{abstract}
В статье проведен анализ нефтяного шлама ТОО «ПНХЗ», отобранного из резервуара хранения прямогонного мазута. Содержание воды, нефтепродуктов и механических примесей составило $12,4 \%$, $17,6 \%$ и $70 \%$ соответственно. Образец нефти, выделенный из шлама, был проанализирован на содержание силикагелевых смол, парафинов и асфальтенов, а также был изучен их групповой состав с помощью метода ИК-спектрометрии. Выявлено, что стабилизаторы нефтешлама относятся к парафиновому типу. Для получения информации о начальной и конечной температурах термического разложения исследуемого нефтешлама был использован ТГ/ДСК анализ. Было показано, что нефтепродукты полностью сгорают до температуры $600{ }^{\circ} \mathrm{C}$. Данная температура используется для проведения обжига нефтешлама. Определен фазовый состав механических примесей, выделенных из нефтешлама, методом рентгенофазового анализа на рентгенофазовом дифрактометре D8 Advance (Bruker). По полученным данным выявлено, что основными составляющими минеральной части нефтешлама являются кварцевый песок $(63,1 \%)$ и альбит $(16,5 \%)$. Была подобрана наиболее оптимальная смесь растворителей для извлечения нефтепродуктов из нефтешлама экстракционным методом. Лучшие результаты были получены при применении смеси уайт-спирит : гексен.
\end{abstract}

Ключевые слова: нефтяной шлам, механические примеси, растворитель, экстракция, парафины, смолы, асфальтены, ТГ/ДСК анализ.

\title{
References
}

1 Akhmetov, A.F., Gaisina, A.R., \& Mustafin, I.A. (2011). Metody utilizatsii nefteshlamov razlichnoho proiskhozhdeniia [Utilization methods of oil sludge of different origin]. Neftehazovoe delo - Oil and gas business, 9, 3, 98-101 [in Russian].

2 Wang, J., Liu, T., Huang, Q., Ma, Z., Chi, Y., \& Yan, J. (2017). Production and characterization of high quality activated carbon from oily sludge. Fuel Processing Technology, 162, 13-19. doi:10.1016/j.fuproc.2017.03.017.

3 Liang, J., Zhao, L., Du, N., Li, H., \& Hou, W. (2014). Solid effect in solvent extraction treatment of pre-treated oily sludge. Separation and Purification Technology, 130, 28-33. doi:10.1016/j.seppur.2014.03.027.

4 Viana, F.F., Dantas, T.N., Rossi, C.G., Neto, A.A., \& Silva, M.S. (2015). Aged oil sludge solubilization using new microemulsion systems: Design of experiments. Journal of Molecular Liquids, 210, 44-50. doi:10.1016/j.molliq.2015.02.042.

5 Elektorowicz, M., \& Muslat, Z. (2008). Removal Of Heavy Metals From Oil Sludge Using Ion Exchange Textiles. Environmental Technology, 29(4), 393-399. doi:10.1080/09593330801984290.

6 Hu, J., Gan, J., Li, J., Luo, Y., Wang, G., Wu, L., \& Gong, Y. (2017). Extraction of crude oil from petrochemical sludge: Characterization of products using thermogravimetric analysis. Fuel, 188, 166-172. doi:10.1016/j.fuel.2016.09.068.

7 Zubaidy, E.A., \& Abouelnasr, D.M. (2010). Fuel recovery from waste oily sludge using solvent extraction. Process Safety and Environmental Protection, 88(5), 318-326. doi:10.1016/j.psep.2010.04.001.

8 Ermakov, V., Bogomolov, A., \& Bykov, D. (2012). Oil sludge depository assessment using multivariate data analysis. Journal of Environmental Management, 105, 144-151. doi:10.1016/j.jenvman.2012.03.041.

9 Boiko, G.I., Aitkalieva, G.S., Shaikhutdinov, E.M., Liubchenko, N.P., Maimakov, T.P., Sarmurzina, R.G., et al. (2015). Otsenka sostava asfaltosmoloparafinovykh otlozhenii i nefti mestorozhdeniia «Kumkol» metodami termicheskoho i IKspektroskopicheskoho analizov [Evaluation of the composition of asphalt resin paraffin deposits and oil from the Kumkol field using thermal and IR spectroscopic analyzes]. Neftianoe khoziaistvo - Oil industry, 6, 80-82 [in Russian].

10 Saikial, N.J., Sengupta, P., Gogoi, P.K., \& Borthakur, P.C. (2005). Thermogravimetric combustion kinetics of petroleum effluent treatment plant sludge. Journal of Thermal Analysis and Calorimetry, 79(3), 653-662. doi:10.1007/s10973-005-0592-y.

11 Bai, F., Sun, Y., Liu, Y., Li, Q., \& Guo, M. (2015). Thermal and kinetic characteristics of pyrolysis and combustion of three oil shales. Energy Conversion and Management, 97, 374-381. doi:10.1016/j.enconman.2015.03.007. 